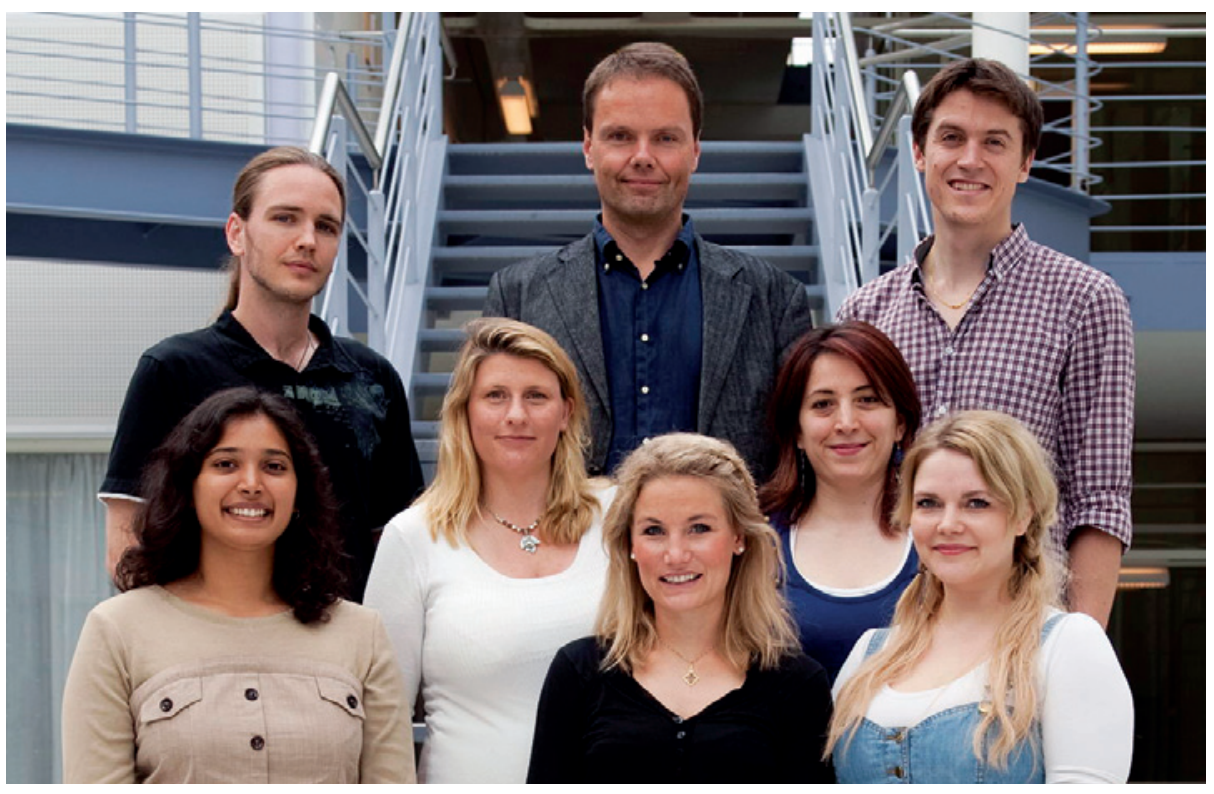

Forskergruppen til Erlend Nagelhus ved Norsk senter for molekylærmedisin, Universitetet i Oslo. Foran: Doktorgradsstipendiat Vinita Rangroo Thrane, forsker Anna E. Thoren, turnuslege Martine Eilert-Olsen, doktorgradsstipendiat Nadia Nabil Haj-Yasein, doktorgradsstipendiat Gry Fluge Vindedal. Bak: postdoktor John M. Burkhardt, gruppeleder Erlend Nagelhus, doktorgradsstipendiat Alexander Stanley Thrane. Foto Gunnar F. Lothe

\section{Vannkanaler regulerer kalsiumsignaler ved hjerneødem}

Norske studier gir ny kunnskap om hvordan vannkanalen akvaporin 4
Ordforklaringer

Akvaporiner: | 1992 oppdaget gruppen til

Peter Agre i USA det første vannkanalproteinet. Det ble senere kalt akvaporin 1 (AQP1). Agre fikk i 2003 nobelprisen i kjemi for denne oppdagelsen.

Akvaporiner er membrankanaler som formidler rask og selektiv transport av vann. I 1994 fant Agres gruppe at hjernen inneholder cDNA for et hittil ukjent akvaporin, som senere ble kalt akvaporin 4 (AQP4) (1). Sammen med Agre og Ole Petter Ottersen oppdaget Erlend Nagelhus AQP4-proteinets lokalisering i 1997 (2).

In vivo-multifotonmikroskopi: Laserbasert teknikk for bildeopptak i levende fors $\emptyset$ ksdyr

\section{Litteratur}

1. Hem E. Vannkanaler har betydning ved hjerneslag. Tidsskr Nor Lægeforen 2007; 127: 1013.

2. Nielsen S, Nagelhus EA, Amiry-Moghaddam M et al. Specialized membrane domains for water transport in glial cells: high-resolution immunogold cytochemistry of aquaporin-4 in rat brain. J Neurosci 1997; 17: 171-80.

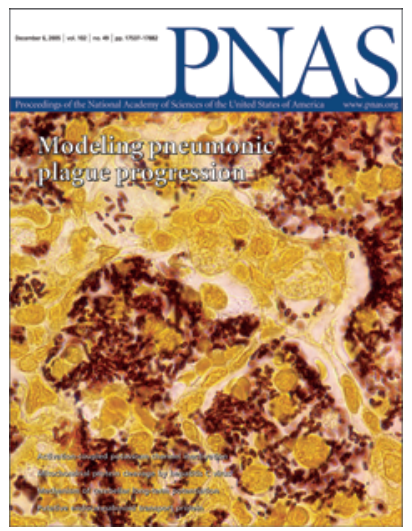

Norske forskere har nylig publisert to artikler i tidsskriftet Proceedings of the National Academy of Sciences of the USA $(1,2)$. I den første studien, med doktorgradsstipendiat Alexander Stanley Thrane som førsteforfatter, ble hjerneødem indusert på anesteserte forsøksmus, der kalsiumsignaler i hjernebarken så ble studert ved hjelp av in vivomultifotonmikroskopi (1). Normale mus ble sammenliknet med genmodifiserte mus uten vannkanalen akvaporin 4 . Resultatene viste at akvaporin 4 endrer gliacellenes totale vanninnhold, og regulerer kalsiumsignaler og frigjøring av adenosintrifosfat. Dette kan påvirke nervecellenes funksjon.

- Studien ble utført i samarbeid med University of Rochester i New York og ble trukket frem i det anerkjente tidsskriftet Nature Reviews Neuroscience (3). Oppdagelsen av disse signalmekanismene kan gi grunnlag for nye behandlingsprinsipper ved hjerneødem, sier forsker Erlend Nagelhus, som er sisteforfatter på begge artiklene.

I den andre studien, med doktorgradsstipendiat Nadia Nabil Haj-Yasein som førsteforfatter, ble genet som koder for akvaporin 4 selektivt fjernet fra gliacellene (2). Resultatene viste at det er gliacellene som regulerer transporten av vann over blod-hjerne-barrieren. Dette innebærer at nye legemidler mot hjerneødem må ha evne til å passere endotelcellene, sier Nagelhus.

\section{Studier av gliaceller}

Studiene utgår fra Erlend Nagelhus' forskergruppe ved Norsk senter for molekylærmedisin (www.ncmm.uio.no), Universitetet i Oslo. Forskergruppen er særlig opptatt av gliaceller og kombinerer elektrofysiologiske målinger med funksjonelle bildeopptak. Ved hjelp av multifotonmikroskopi studeres begivenheter på synapsenivå i hjernebarken til levende forsøksdyr. Gruppen er særlig opptatt av vann- og ionehomøostase i synapser og hvordan glia regulerer blodtilstrømning ved nevronal aktivitet.

\section{Erlend Hem}

erlend.hem@medisin.uio.no

Tidsskriftet

\section{Litteratur}

1. Thrane AS, Rappold PM, Fujita T et al. Critical role of aquaporin-4 (AQP4) in astrocytic $\mathrm{Ca} 2+$ signaling events elicited by cerebral edema. Proc Natl Acad Sci USA 2011; 108: 846-51.

2. Haj-Yasein NN, Vindedal GF, Eilert-Olsen $M$ et al. Glial-conditional deletion of aquaporin-4 (Aqp4) reduces blood-brain water uptake and confers barrier function on perivascular astrocyte endfeet. Proc Natl Acad Sci USA 2011; 108: 17815-20.

3. Welberg L. Glia: aquaporin: not so swell? Nat Rev Neurosci 2011; 12: 66 